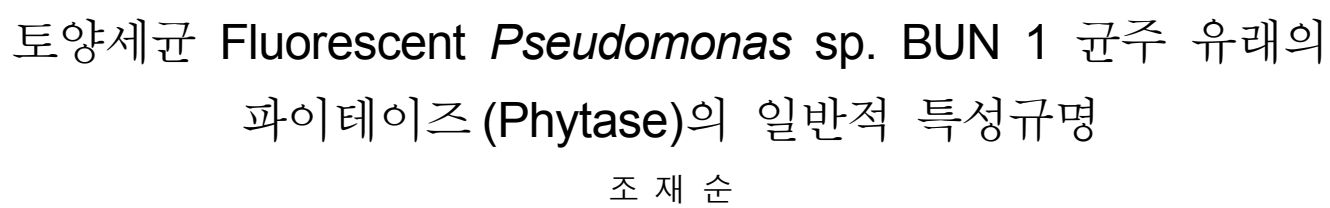

건국대학교 동물생명과학대학 동물생산환경학전공

\title{
General Properties of Phytase Produced by Fluorescent Pseudomonas sp. BUN1
}

\author{
Jaie Soon Cho \\ Department of Animal Sciences \& Environment, College of Animal Bioscience \& Technology, Konkuk University, \\ 1 Hwayang-dong, Gwangjin-gu, Seoul 143-701, Korea
}

요 약

우사주변 경작지 토양으로부터 세포내 파이테이즈 (phytase) 생산능력이 우수한 Fluorescent Pseudomonas sp. BUN1 세균성 균주를 분리, 동정하였다. 그 균주로부터 유래한 BUN1 파이테이즈 (phytase) 효소를 각각 양이온, 음이온 크로마토그래피 기 법을 이용하여 부분정제하여 효소적 특성을 규명한 결과, 각각 $40^{\circ} \mathrm{C}$ 와 $\mathrm{pH} 5.5$ 에서 최적의 효소활성을 나타내었다. $\mathrm{BUN} 1$ 파이테이즈 (phytase)는 효소의 기질특이성 측면에서 다른 유기인산화합물에 비해 특히 피틴태인 (phytate)의 분해이용성이 매 우 우수한 반면, 구리 $\left(\mathrm{Cu}^{2+}\right)$, 카드뮴 $\left(\mathrm{Cd}^{2+}\right)$, 아연 $\left(\mathrm{Zn}^{2+}\right)$ 과 같은 금속 2 가이온에 대하여 그 효소활성이 강하게 억제되었다. 또한 BUN1 균주의 효소생산 배지 (PSM) $\left[0.5 \%\right.$ sodium phytate, $0.5 \%\left(\mathrm{NH}_{4}\right)_{2} \mathrm{SO}_{4}, 0.5 \% \mathrm{KCl}, 0.01 \% \mathrm{MgSO}_{4} \cdot 7 \mathrm{H}_{2} \mathrm{O}, 0.01 \% \mathrm{CaCl}_{2}$ $\cdot 2 \mathrm{H}_{2} \mathrm{O}, 0.01 \% \mathrm{NaCl}, 0.001 \% \mathrm{FeSO}_{4} \cdot 7 \mathrm{H}_{2} \mathrm{O}, 0.001 \% \mathrm{MnSO}_{4} \cdot 4 \mathrm{H}_{2} \mathrm{O} ; \mathrm{pH}$ 6.5]에 탄소원으로서 옥수수전분 (corn starch)의 첨가는 조사된 다른 탄소 배지원에 비하여 현저하게 파이테이즈 (phytase) 생산을 촉진시켰다.

(주요어 : Bacterial, Intracellular, Pseudomonas, Phytase, Phytate)

\section{I . INTRODUCTION}

Phytase (myo-inositol hexakisphosphate phosphohydrolase, EC 3.1.3.8 and EC 3.1.3.28) belongs to a member of histidine acid phosphatases and initiates the hydrolysis of phosphate from phytate (myo-inositol hexakisphosphate), which is the major phosphate reserve in cereal grains, legumes, and oilseeds industrially used for manufacturing animal feeds (Haefner et al., 2005; Reddy et al., 1982). Since monogastric animals, like swine and poultry have very low or no phytase activities in their digestive tracts, most of the ingested phytate is not metabolized and discharged in their feces, contributing to environmental concerns in areas with concentrated livestock production(Comon, 1989; Wodzinski and Ullah, 1996). Phytate also forms insoluble complexes with nutritionally important metals such as iron, zinc, calcium, magnesium, and proteins, thereby showing antinutritional effects (Rojas and Scott, 1968). Supplemental phytase to diets for these animals effectively improves the bioavailability of phytate-phosphorus, thus alleviating phosphorus pollution.

So far, a variety of phytases have been widely found in plants and microorganisms (Oh et al., 2004). Although two filamentous fungal-derived strains, Aspergillus niger and Aspergillus ficuum are currently available for the commercial production, studies are ongoing to identify more desirable phytases and to induce their over-expression in industrially attractive host, such as yeast or E. coli through recombinant DNA work for animal feed application so as to overcome the defects of the fungal enzyme with regard to substrate specificity and catalytic efficiency (Chi et al., 2009; Huang et al., 2009; Hussin et al., 2007).

In this study, an intracellular phytase produced by a bacterial isolate, fluorescent Pseudomonas sp. BUN1 was partially characterized.

Corresponding author : Jaiesoon-Cho, Department of Animal Sciences \& Environment, College of Animal Bioscience \& Technology, Konkuk University, 1 Hwayang-dong, Gwangjin-gu, Seoul 143-701, Korea Tel: +82-2-450-3375, Fax: +82-2-455-1044, E-mail: chojs70@konkuk.ac.kr 


\section{MATERIALS \& METHODS}

\section{Screening of a phytase-producing bacterium}

The screening of a phytase-producing bacterium was performed by a modified method of Richardson and Hadobas (1997). Various soil samples were collected from cultivable fields near cowsheds. Approximately fifty grams of each soil were suspended in $100 \mathrm{ml}$ of sterile $0.9 \%(\mathrm{w} / \mathrm{v}) \mathrm{NaCl}$, and subjected to reciprocal shaking $(200 \mathrm{rpm}, 2 \mathrm{~h})$. After $20 \mathrm{~min}$ settling period, each aliquot $(1 \mathrm{ml})$ of the soil suspension was inoculated into $100 \mathrm{ml}$ of phytase-synthetic medium (PSM) in $500 \mathrm{ml}$ Erlenmeyer flasks. This synthetic medium was composed of $(\mathrm{g} / \mathrm{l})$ : [sodium phytate, $5 ;\left(\mathrm{NH}_{4}\right) 2 \mathrm{SO}_{4}, 5 ; \mathrm{KCl}, 5$; $\mathrm{MgSO}_{4} \cdot 7 \mathrm{H}_{2} \mathrm{O}, 0.1 ; \mathrm{CaCl}_{2} \cdot 2 \mathrm{H}_{2} \mathrm{O}, 0.1 ; \mathrm{NaCl}, 0.1 ; \mathrm{FeSO}_{4} \cdot$ $\left.7 \mathrm{H}_{2} \mathrm{O}, 0.01 ; \mathrm{MnSO}_{4} \cdot 4 \mathrm{H}_{2} \mathrm{O}, 0.01 ; \mathrm{pH} 6.5\right]$, using sodium phytate as a sole source of carbon and phosphate, and each flask was incubated at $28^{\circ} \mathrm{C}$ for $48 \mathrm{~h}$ with vigorously shaking. $1 \mathrm{ml}$ of the cultures was appropriately diluted, plated on PSM, and incubated at $28^{\circ} \mathrm{C}$ for $3 \sim 4$ days. Diversified morphological types of bacterial colonies were selected and purified. Each of the isolated strains was grown in $10 \mathrm{ml}$ of PSM broth at $28^{\circ} \mathrm{C}$ for $48 \mathrm{~h}$ on a reciprocal shaker $(200$ $\mathrm{rpm})$. Cells were harvested by centrifugation at $5,000 \mathrm{~g}$ for $10 \mathrm{~min}$, resuspended in $1 \mathrm{ml}$ of $50 \mathrm{mM}$ acetate buffer $(\mathrm{pH}$ 5.5) and ground with $0.2 \mathrm{~g}$ of glass beads (425 600 microns; Sigma) using Bead-Beater (Biospect Products). The supernatant fluids were collected by centrifugation, and used for the phytase activity assay.

\section{Identification of a phytase-producing bacterium}

The bacterial strain showing the highest phytase activity was identified by Gram staining, as well as biochemical, and physiological tests. The morphology of the isolated strain was observed by a scanning electron microscopy (SEM). The metabolic characteristics of the isolated strain were examined by the API kit(Bio-Merieux). The cellular fatty acid composition of the isolated strain was analyzed using gas chromatography (Hewlet-Packard 6890A) as described by Ikemoto et al. (1978).

\section{Phytase assay}

Phytase assay was done as duplicates in $1 \mathrm{ml}$ volume at $40^{\circ} \mathrm{C}$ for $30 \mathrm{~min}$ in $50 \mathrm{mM}$ acetate buffer $(\mathrm{pH} \mathrm{5.5)} \mathrm{containing}$ $1 \mathrm{mM}$ sodium phytate by the modified method of Heinonen and Lahti (1980) unless otherwise stated. The liberated inorganic phosphates were spectrophotometrically quantitated using a freshly prepared acetone-acid-molybdate (AAM) reagent consisting of acetone, $5 \mathrm{~N}$ sulfuric acid, and $10 \mathrm{mM}$ ammonium molybdate $(2: 1: 1, \mathrm{v} / \mathrm{v})$. The assay was stopped by adding $2 \mathrm{ml}$ AAM solution per assay tube. After $30 \mathrm{sec}, 0.2$ $\mathrm{ml}$ of $1 \mathrm{M}$ citric acid was admixed to each tube, and absorbance was read at $405 \mathrm{~nm}$. One unit of phytase activity was defined as the amount of enzyme required to liberate 1 $\mu \mathrm{mol}$ of phosphate per minute under the assay condition. The enzyme activity assay $(\mathrm{n}=2)$ with other phosphorylated compounds was performed as described above using $1 \mathrm{mM}$ of each substrate. Acid phosphatase activity $(n=2)$ was assayed using $p$-nitrophenylphosphate as described by Greiner et al. (1993). The release of $p$-nitrophenol was measured at absorbance of $410 \mathrm{~nm}$. The $\mathrm{pH}$ profile of the phytase activity $(\mathrm{n}=2)$ was determined at $40^{\circ} \mathrm{C}$ with a $\mathrm{pH}$ range from 2.5 to 8.5 using glycine- $\mathrm{HCl}$ (2.5-3.5), sodium-acetate (4.5-5.5), bistris (6.5), and tris- $\mathrm{HCl}(7.5-8.5)$ buffers at $50 \mathrm{mM}$ each. The optimum temperature of the phytase activity $(\mathrm{n}=2)$ was also measured at various temperatures ranging from 20 to $80^{\circ} \mathrm{C}$ with a $\mathrm{pH} 5.5$.

\section{Protein measurement}

Protein concentration was measured by the method of Bradford (1976) using a protein assay kit (Bio-Rad) with bovine serum albumin as the standard.

\section{Partial purification of BUN1 phytase}

The partial purification of BUN1 phytase was done through a modified method previously described by Ullah et al. (2002). BUN1 strain was inoculated into $1000 \mathrm{ml}$ of PSM and aerobically incubated at $28^{\circ} \mathrm{C}$ for $72 \mathrm{~h}$ with reciprocal shaking $(200 \mathrm{rpm})$. The cells were harvested by centrifugation at $10,000 \mathrm{~g}$ for $15 \mathrm{~min}$ at $4^{\circ} \mathrm{C}$, resuspended in $50 \mathrm{mM}$ Tris buffer ( $\mathrm{pH} 8.0$ ), and homogenized with $10 \mathrm{~g}$ of glass beads (425-600 microns; Sigma) in a pre-chilled vortexing mixer (Scientific Industries). The homogenate was then centrifuged at $10,000 \mathrm{~g}$ for $20 \mathrm{~min}$ at $4^{\circ} \mathrm{C}$. After filtering the supernatant fluid with disposable syringe filter unit $(0.45 \mu \mathrm{m}$; ADVANTEC), the crude extract was used for enzyme purification. A BioLogic HR LC system (Bio Rad) was used to perform chromatography. The crude enzyme was loaded onto an anion-exchange UNO Q-6 column (12 by $53 \mathrm{~mm}$; Bio Rad) that had previously been equilibrated with buffer A $(50 \mathrm{mM}$ Tris buffer; $\mathrm{pH}$ 8.0). The column was washed with the same buffer and developed by running a linear salt gradient of 0 to $1 \mathrm{M} \mathrm{NaCl}$ in the buffer at a flow rate of $2.0 \mathrm{ml} / \mathrm{min}$. The peak fractions of phytase activity were pooled and diluted 
ten-fold with buffer B (25 mM acetate buffer; $\mathrm{pH}$ 5.5). Subsequently, the dilute was applied to a cation-exchange UNO S-6 column (12 by $53 \mathrm{~mm}$; Bio Rad) that had previously been equilibrated with the acetate buffer, and the phytase was eluted with a linear salt gradient of 0 to $1 \mathrm{M}$ $\mathrm{NaCl}$ in the same buffer at a flow rate of $2.0 \mathrm{ml} / \mathrm{min}$. The active fractions were pooled, dialyzed in $10 \mathrm{mM}$ Tris buffer $(\mathrm{pH} 7.5)$, and stored at $-80^{\circ} \mathrm{C}$ for further analysis.

\section{Effect of additional carbon sources and nitrogen sources on phytase production}

BUN1 strain was inoculated into $50 \mathrm{ml}$ of PSM in a 500 $\mathrm{ml}$ Erlenmeyer flask as a basal medium, and incubated at 28 $\mathrm{C}^{\circ}$ for $36 \mathrm{~h}$ on a reciprocal shaker $(200 \mathrm{rpm})$. The parameters tested consist of carbon sources including glucose, glycerol, galactose, raffinose, maltose, sucrose, cellobiose, lactose, and corn starch at $0.5 \%(\mathrm{w} / \mathrm{v})$, and nitrogen sources including ammonium chloride, ammonium nitrate, urea, casein hydrolysate, tryptone, peptone, casamino acid, beef extract, and yeast extract at $0.5 \%(\mathrm{w} / \mathrm{v})$. After cultivation, the crude enzyme extracts were prepared as described above and the phytase assay done. The data was expressed as means from three experiments.

\section{RESULTS \& DISCUSSION}

A number of bacterial colonies were isolated, and the strains, which can grow on PSM containing sodium phytate as a sole source of phosphate and carbon, were selected. Among about three hundred strains isolated, BUN1 strain showed the highest phytase activity in the cell pellet (data not shown). The colony morphology of BUN1 strain was round with cream color. The strain was a motile, gram-negative, and rod-shaped bacterium(Fig. 1) especially producing fluorescent pigment in King's B medium (King et al., 1954). The basic biochemical and physiological properties of BUN1 strain are shown in Table 1. A cellular fatty acid analysis of the strain revealed the presence of $\mathrm{C} 16: 1 \mathrm{w} 7 \mathrm{c} / \mathrm{C} 15$ iso $2 \mathrm{OH}$ (34.3\%), $\mathrm{C} 16: 0(26.6 \%)$, and $\mathrm{C} 18: \mathrm{w} 7 \mathrm{c}(15.4 \%)$ as the major constituents, with a minor presence of $\mathrm{C} 17: 0$ cyclo $(2.2 \%)$. Based on these biochemical and physiological characteristics, BUN1 strain was assigned to a fluorescent Pseudomonas sp. Generally, Pseudomonas strains which are ubiquitous group of microorganisms found in soil, seem to play a crucial role in utilizing inositol phosphates which are considered to be recalcitrant in soils and waterbodies, even though a clear mechanism of their behavior in the environment still remains elusive (Turner et al., 2007). In previous study, fluorescent

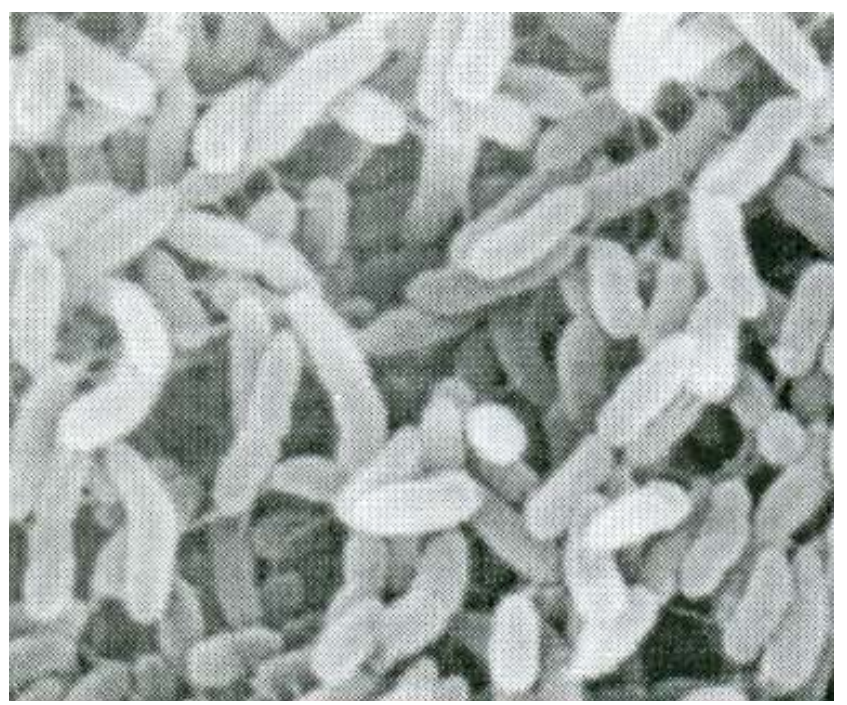

Fig. 1. Scanning electron microscope (SEM) of Pseudomonas sp. BUN1.

Pseudomonas strains markedly exhibited phytase activity in comparison with nonfluorescent Pseudomonas strains (Richardson and Hadobas, 1997). When BUN1 strain was cultured in PSM, no phytase activity was detected in the culture medium. During the osmotic shock, no release of the phytase was observed. Therefore, BUN1 phytase was regarded as a

Table 1. Basic biochemical and physiological properties of strain BUN1

\begin{tabular}{lc}
\hline Characteristics & Strain BUN1 \\
\hline \hline Enzyme activity of & + \\
Cytochrome oxidase & + \\
Arginine dihydrolase & - \\
Lysine decarboxylase & - \\
Ornithine decarboxylase & - \\
ß-galactosidase & - \\
Production of & + \\
$\quad$ Indole & - \\
$\quad$ Acetoin & - \\
$\quad$ Urease & + \\
H2S & + \\
Gelatin liquefaction & - \\
Nitrate reduction & - \\
Denitrification & + \\
Glucose fermentation & \\
Citrate utilization & + \\
Assimilation of & + \\
$\quad$ Glucose & + \\
$\quad$ Arabinose & + \\
$\quad$ Mannose & + \\
Mannitol & + \\
Glucetylglucosamine & + \\
Carprate & + \\
Malate & + \\
Citrate & + \\
\hline
\end{tabular}

+ : Positive $-:$ Negative. 
cytoplasmatic enzyme. On the other hand, several Bacillus species (Choi et al., 2001; Kerovuo et al., 1998; Kim et al., 1998), Enterobacter sp. (Yoon et al., 1996) and Lactobacillus amylovorus (Hussin et al., 2007) phytase exist as extracellular forms.

The intracellular BUN1 phytase was partially purified by cation and anion chromatography with a yield of $22 \%$ and its specific activity was $50.15 \mathrm{U} / \mathrm{mg}$ of protein at $\mathrm{pH} 5.5$ and $40^{\circ} \mathrm{C}$. The enzyme showed a $\mathrm{pH}$ optimum of 5.5 (Fig. 2A) and more than $80 \%$ of the maximal activity was observed at $\mathrm{pH}$ values between 4.5-6.5, which closely matches the $\mathrm{pH}$ range at potential sites of action, like the salivary glands (pH 5.0) and upper part of the small intestine ( $\mathrm{pH} 4.0-6.0$ ) (Casey and Walsh, 2003). Most of fungal and yeast phytases were largely active at acidic pH(Dvorakova et al., 1997; Han and Lei., 1999; Han et al., 1999; Liu et al., 1999; Segueilha et al., 1992), while some bacterial phytases, such as Bacillus sp. (Choi et al., 2001; Kerovuo et al., 1998; Kim et al., 1998), Enterobacter sp. (Yoon et al., 1996) and Aeromonas sp. (Seo et al., 2005) exhibited optimum activity at neutral or alkaline $\mathrm{pH}$ of 6.5-8.5. The temperature optimum of the enzyme was found at $40^{\circ} \mathrm{C}$ (Fig. 2B), as compared that the well-known Aspergillus sp. and Bacillus sp. DS11 phytase showed the optimal activity at higher temperature of $60^{\circ} \mathrm{C}$ and $70^{\circ} \mathrm{C}$, respectively, but their percentage optimal activity retained at the physiological temperature $\left(37-40^{\circ} \mathrm{C}\right.$ ) was no more than $40 \%$ (Dvorakova et al., 1997; Liu et al., 1999; Kim et al., 1998).

The effects of inhibitors and metal ions on BUN 1 phytase activity were examined using sodium phytate as a substrate (Table 2). The enzyme activity was strongly inhibited by $\mathrm{Cu}^{2+}, \mathrm{Cd}^{2+}$, and $\mathrm{Zn}^{2+}$, and moderately inhibited

by $\mathrm{Ba}^{2+}, \mathrm{Co}^{2+}, \mathrm{Mn}^{2+}$, and EDTA at $5 \mathrm{mM}$ each. These cations may form insoluble complexes with phytate and therefore decrease net concentration of the active substrate in the activity assay. This may interrelate with previous report that the stability of metal ion-phytate complexes at $\mathrm{pH} 7.4$ was found to decrease in the following order: $\mathrm{Cu}^{2+}>\mathrm{Zn}^{2+}>$ $\mathrm{Ni}^{2+}>\mathrm{Co}^{2+}>\mathrm{Mn}^{2+}>\mathrm{Fe}^{3+}>\mathrm{Ca}^{2+}$ (Wyss et al., 1999). Meanwhile, $\mathrm{Ca}^{2+}, \mathrm{Mg}^{2+}$, and PMSF did not have a significant impact on the enzyme activity. To date, most of phytases have not been described as metalloenzymes, except that some Bacillus sp. phytase required calcium for active conformation and thermostability, and readily lost the enzyme activity through its removal by EDTA (Choi et al., 2001; Kerovuo et al., 2000). BUN1 phytase had high activity for phytate, but none or low activity on other phosphorylated compounds

Table 2. Effects of metal ions and inhibitors on partially purified BUN1 phytase

\begin{tabular}{lc}
\hline Reagents $(5 \mathrm{mM})$ & Relative activity $(\%)$ \\
\hline \hline None & 100 \\
$\mathrm{MgCl}_{2}$ & 81 \\
$\mathrm{CdCl}_{2}$ & 1.7 \\
$\mathrm{AlCl}_{3}$ & 108 \\
$\mathrm{BaCl}_{2}$ & 22.6 \\
$\mathrm{LiCl}$ & 114 \\
$\mathrm{ZnCl}_{2}$ & 1.7 \\
$\mathrm{CaCl}_{2}$ & 95 \\
$\mathrm{CuCl}_{2}$ & 1.9 \\
$\mathrm{CoCl}_{3}$ & 39 \\
$\mathrm{MnCl}_{2}$ & 32.3 \\
$\mathrm{EDTA}$ & 47.4 \\
$\mathrm{PMSF}$ & 77 \\
\hline
\end{tabular}

${ }^{a} 100 \%$ activity was taken when phytase assay was performed at $40^{\circ} \mathrm{C}$ and $\mathrm{pH} 5.5$ in the absence of metal ions and inhibitors.

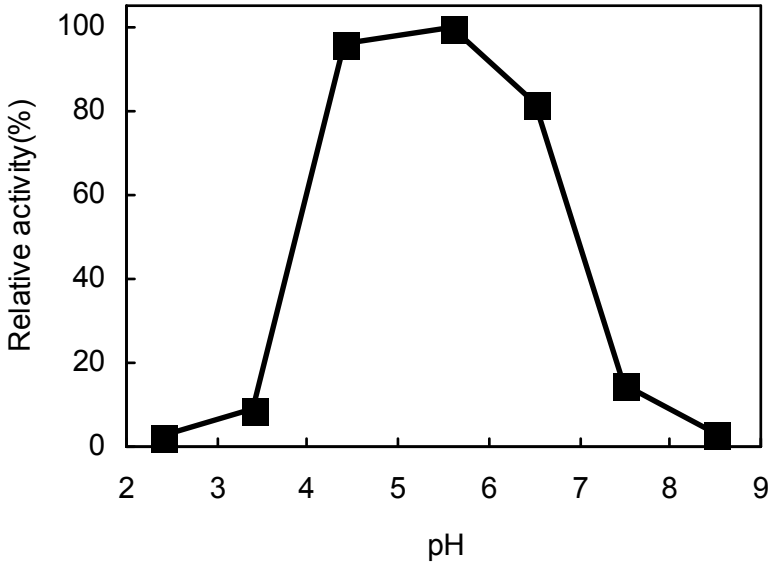

【A】

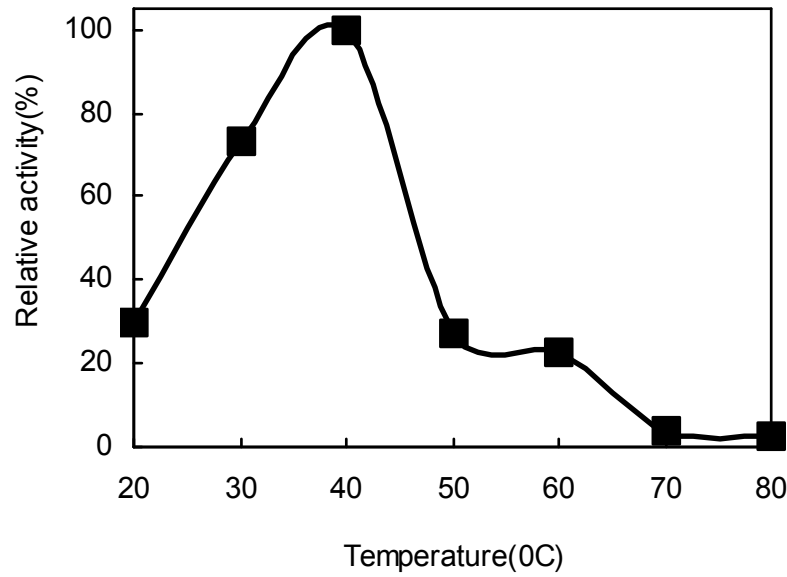

[B】

Fig. 2. Effect of $\mathrm{pH}(\mathrm{A})$ and temperature $(B)$ on the activity of partially purified BUN1 phytase. The relative activity was expressed as a percentage of the maximum activity taken as $100 \%$. 
including p-nitrophenylphosphate, a representative substrate for acid phosphatase (Table 3). These results indicate that the enzyme is very specific for phytate. In contrast, many fungal phytases have broad specific activity for phosphorylated compounds such as glucose-6-phosphate and fructose 1,6-bis phosphate (Wyss et al., 1999).

In fluorescent Pseudomonas sp. BUN1, the phytase seems to be inducible under carbon limitation only in the presence of phytate, like other phytase-producing soil isolates, Klebsiella species (Greiner et al., 1997). There was no difference in the phytase activities when inorganic nitrogen sources were added to the basal medium, PSM. However, incorporation of organic nitrogen sources into the medium which contains enough inorganic phosphate increased the growth rate of the strain, bearing no detectable phytase activity (data not shown). As shown in Table 4, BUN1 strain exhibited a high growth rate when glucose or glycerol was used as the additional carbon source, whereas its specific phytase activity per $\mathrm{mg}$ of protein was low. It is not clear whether this effect is due to repression by glucose or catabolite, though catabolic repression on the enzyme production occurs frequently in microorganism when the cell is grown in a medium containing more than one utilizable growth substrate (Lan et al., 2002). BUN1 strain may utilize glucose and glycerol more rapidly, resulting in an accumulation of large amount of organic acid such as acetic acid, which not only reduces $\mathrm{pH}$ of the medium, but also does harm to the bacterial cells, thus suppressing the enzyme synthesis. On the other hand, the addition of corn starch was found to significantly induce the phytase activity in comparison with other carbon sources tried. This is compatible with an earlier study by Shieh and Ware (1968) that the phytase production of fungal strain, Aspergillus niger NRRL 3135 was also greatly influenced by the type of corn starch used in the culture medium. It may be supposed that a less soluble phytate enclosed by corn starch in the medium was hydrolyzed slowly, which triggers to the continuous induction of phytase production by preventing of the end-product inhibition.

From an applied perspective, BUN1 phytase can be an interesting candidate due to its strict substrate specificity, and physiologically-relevant temperature and $\mathrm{pH}$ profile. Further recombinant DNA technology including gene cloning will support an efficient strategy for mass production of the enzyme as an environmental-friendly feed additive.

\section{ABSTRACT}

A bacterial strain producing intracellular phytase was isolated from cultivable soil near cowsheds and identified as
Table 3. Substrate specificity of partially purified BUN1 phytase

\begin{tabular}{lc}
\hline \multicolumn{1}{c}{ Substrate $(1 \mathrm{mM})$} & ${ }^{a}$ Relative activity $(\%)$ \\
\hline \hline Sodium phytate & 100 \\
Sodium pyrophosphate & 11 \\
ATP & 14 \\
ADP & 11 \\
AMP & 0 \\
Fructose-1-phosphate & 0 \\
Fructose-6-phosphate & 0 \\
Glucose-1-phosphate & 0 \\
a-glycerophosphate & 2.8 \\
B-glycerophosphate & 3.6 \\
a-naphtylphosphate & 2.0 \\
p-nitrophenylphosphate & 2.9 \\
\hline
\end{tabular}

${ }^{a} 100 \%$ activity was taken when the phytase was assayed with sodium phytate at $40^{\circ} \mathrm{C}$ and $\mathrm{pH} 5.5$.

Table 4. Effects of additional carbon sources on BUN1 phytase activity and growth

\begin{tabular}{|c|c|c|}
\hline $\begin{array}{c}\text { Carbon } \\
\text { sources }(0.5 \%)\end{array}$ & $\begin{array}{l}{ }^{b} \text { Growth } \\
\left(\mathrm{OD}_{600}\right)\end{array}$ & $\begin{array}{l}\text { Specific phytase activity } \\
\text { (U/mg of protein) }\end{array}$ \\
\hline 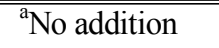 & 0.519 & 0.59 \\
\hline Raffinose & 0.669 & 1.37 \\
\hline Glucose & 1.471 & 0.13 \\
\hline Glycerol & 1.386 & 0.53 \\
\hline Galactose & 1.256 & 0.78 \\
\hline Sucrose & 1.212 & 0.84 \\
\hline Lactose & 0.628 & 1.33 \\
\hline Cellobiose & 0.651 & 1.27 \\
\hline Maltose & 0.550 & 1.39 \\
\hline Corn starch & 0.780 & 4.05 \\
\hline
\end{tabular}

${ }^{a}$ Cultivation was carried out at $28^{\circ} \mathrm{C}$ for $36 \mathrm{~h}$ in PSM $[0.5 \%$ sodium phytate, $0.5 \%\left(\mathrm{NH}_{4}\right)_{2} \mathrm{SO}_{4}, 0.5 \% \mathrm{KCl}, 0.01 \% \mathrm{MgSO}_{4} \cdot$ $7 \mathrm{H}_{2} \mathrm{O}, 0.01 \% \mathrm{CaCl}_{2} \cdot 2 \mathrm{H}_{2} \mathrm{O}, 0.01 \% \mathrm{NaCl}, 0.001 \% \mathrm{FeSO}_{4} \cdot 7 \mathrm{H}_{2} \mathrm{O}$, $\left.0.001 \% \mathrm{MnSO}_{4} \cdot 4 \mathrm{H}_{2} \mathrm{O} ; \mathrm{pH} 6.5\right]$ as a basal medium.

${ }^{\mathrm{b}}$ Bacterial growth was determined by measuring the turbidity at OD $600 \mathrm{~nm}$.

a fluorescent Pseudomonas sp. BUN1. The BUN1 phytase, partially purified by cation and anion exchange chromatography, exhibited its optimal activity at $40^{\circ} \mathrm{C}$ and $\mathrm{pH} 5.5$. As for substrate specificity, it was very specific for phytate and showed little activity on other phosphorylated conjugates. Its activity was greatly inhibited by metal ions such as $\mathrm{Cu}^{2+}$, $\mathrm{Cd}^{2+}$, and $\mathrm{Zn}^{2+}$. Addition of corn starch to PSM (phytasesynthetic medium) $\left[0.5 \%\right.$ sodium phytate, $0.5 \%\left(\mathrm{NH}_{4}\right)_{2} \mathrm{SO}_{4}$, $0.5 \% \mathrm{KCl}, 0.01 \% \mathrm{MgSO}_{4} \cdot 7 \mathrm{H}_{2} \mathrm{O}, 0.01 \% \mathrm{CaCl}_{2} \cdot 2 \mathrm{H}_{2} \mathrm{O}, 0.01 \%$ $\mathrm{NaCl}, \quad 0.001 \% \quad \mathrm{FeSO}_{4} \cdot 7 \mathrm{H}_{2} \mathrm{O}, \quad 0.001 \% \quad \mathrm{MnSO}_{4} \cdot 4 \mathrm{H}_{2} \mathrm{O} ; \quad \mathrm{pH}$ 6.5] for the phytase production significantly induced its enzyme activity in comparison with other carbon sources tested.

(Key words : Bacterial, Intracellular, Pseudomonas, Phytase, Phytate) 


\section{REFERENCES}

1. Bradford, M. M. 1976. A rapid and sensitive method of the quantitation of microgram quantities of protein utilizing the principle of protein dye binding. Analytical Biochemistry. 72:248-254.

2. Casey, A. and Walsh, G. 2003. Purification and characterization of extracellular phytase from Aspergillus niger ATCC 9142. Bioresource Technology. 86:183-188.

3. Chi, Z., Chi, Z., Zhang, T., Liu, G., Li, J. and Wang, X. 2009. Production, characterization and gene cloning of the extracellular enzymes from the marine-derived yeasts and their potential applications. Biotechnology Advances. 27:236-255.

4. Choi, Y. M., Suh, H. J. and Kim, J. M. 2001. Purification and properties of extracellular phytase from Bacillus sp. KHU-10. Journal of Protein Chemistry. 20:287-292.

5. Comon, F. H. 1989. Biological availability of phosphorus for pigs. Nature. 143:370-380.

6. Dvorakova, J., Volfova, O. and Kopecky, J. 1997. Characterization of phytase produced by Aspergillus niger. Folia Microbiology. 42:349-352.

7. Greiner, R., Haller, E., Konietzny, U. and Jany, K. D. 1997. Purification and characterization of a phytase from Klebsiella terrigena. Archives of Biochemistry and Biophysics. 341:201206.

8. Greiner, R., Konietzny, U. and Jany, K. D. 1993. Purification and characterization of two phytase from Escherichia coli. Archives of Biochemistry and Biophysics. 303:107-113.

9. Haefner, S., Knietsch, A., Scholten, E., Braun, J., Lohscheidt, M. and Zelder, O. 2005. Biotechnological production and applications of phytases. Applied Microbiology and Biotechnology. 68:588-597.

10. Han, Y. M. and Lei, X. G. 1999. Role of glycosylation in the functional expression of an Aspergillus niger phytase (phyA) in Pichia pastoris. Archives of Biochemistry and Biophysics. 364:83-90.

11. Han, Y. M., Wilson, D. B. and Lei, X. G. 1999. Expression of an Aspergillus niger phytase gene (phy A) in Saccharomyces cerevisiae. Applied and Environmental Microbiology. 65:1915-1918.

12. Heinonen, J. K. and Lahti, R. J. 1980. A new and convenient colorimetric determination of inorganic orthophosphate and its application to the assay of inorganic pyrophosphatase. Analytical Biochemisry. 113: 313-317.

13. Huang, H., Shao, N., Wang, Y., Luo, H., Yang, P., Zhou, Z., Zhan, Z. and Yao, B. 2009. A novel beta-propeller phytase from Pedobacter nyackensis MJ11 CGMCC2503 with potential as an aquatic feed additive. Applied Microbiology and Biotechnology. Published on line: January 13 (DOI 10.1007/ s00253-008-1835-1).

14. Hussin, A. S. M., Farouk, A. E., Greiner, R., Salleh, H. M. and Ismail, A. F. 2007. Phytate-degrading enzyme production by bacteria isolated from Malaysian soil. World Journal of Microbiology and Biotechnology. 23:1653-1660.

15. Ikemoto, S., Katoh, K. and Komagata, K. 1978. Cellular fatty acid composition in methanol-utilizing bacteria. Journal of General and Applied Microbiology. 24:41-49.

16. Kerovuo, J., Lappalainen, I. and Reinikainen, T. 2000. The metal dependence of Bacillus subtilis phytase. Biochemistry Biophysics Research Communication. 268: 365-369.

17. Kerovuo, J., Lauraeus, M., Nurminen, P., Kakkinen, N. and Apajalahti, J. 1998. Isolation, characterization, Molecular gene cloning, and sequencing of a novel phytase from Bacillus subtilis. Applied and Environmental Microbiology. 64:2079-2085.

18. Kim, Y. O., Kim, H. K., Bae, K. S., Yu, J. H. and Oh, T. K. 1998. Purification and properties of a thermostable phytase from Bacillus sp. DS11. Enzyme and Microbial Technology. 22:2-7.

19. King, E. O., Ward, M. K. and Raney, D. E. 1954. Two simple media for the demonstration of pyocyanin and fluorescein. Journal of Laboratory Clinical Medicine. 44: 301-307.

20. Lan, G. Q., Abdullah, N., Jalaludin, S. and Ho, Y. W. 2002. Optimization of carbon and nitrogen sources for phytase production by Mitsuokella jalaludinii, a new rumen bacterial species. Letters in Applied Microbiology. 35:157-161.

21. Liu, B. L., Jong, C. H. and Tzeng, Y. M. 1999. Effect of immobilization on $\mathrm{pH}$ and thermal stability of Aspergillus ficuum phytase. Enzyme and Microbial Technology. 25:517-521.

22. Oh, B. C., Choi, W. C., Park, S., Kim, Y. O. and Oh, T. K. 2004. Biochemical properties and substrate specificities of alkaline and histidine acid phytases. Applied Microbiology and Biotechnology. 63:362-372.

23. Reddy, N. R., Sathe, S. K. and Salunkhe, D. K. 1982. Phytases in legumes and cereals. Advance in Food Research. 28:1-92.

24. Richardson, A. E. and Hadobas, P. A. 1997. Soil isolates of Pseudomonas spp. that utilize inositol phosphates. Canadian Journal of Microbiology. 43:509-516.

25. Rojas, S. W. and Scott, M. L. 1968. Factors affecting the nutritive value of cottonseed meal as a protein source in chicken diets. Poultry Science. 48:819-835.

26. Segueilha, L., Lamgrechts, C., Boze, H., Mourin, G. and Galzy, P. 1992. Purification and properties of the phytase from Schwanniomyces castellii. Journal of Fermentation and. Bioengineering. 74:7-11.

27. Seo, M. J., Kim, J. N., Cho, E. A., Park, H., Choi, H. J. and Pyun, Y. R. 2005. Purification and Characterization of a novel extracellular alkaline phytase from Aeromonas sp. Journal of Microbiology and. Biotechnology. 15:745- 748.

28. Shieh, T. R. and Ware, J. H. 1968. Survey of microorganisms for the production of extracellular phytase. Applied Microbiology. 16:1348-1351.

29. Turner, B. L., Richardson, A. E. and Mullaney, E. J. 2007. Inositol phosphates: Linking agriculture and the environment. 1st Ed. CAB International, Oxfordshire, UK.

30. Ullah, A. H. J., Sethumadhavan, K., Mullaney, E. J., Ziegelhoffer, T. and Austin-Phillips, S. 2002. Cloned and expressed fungal phyA gene in alfalfa produces a stable phytase. Biochemical and Biophysical Research Communications. 290: 1343-1348.

31. Wodzinski, R. J. and Ullah, A. H. J. 1996. Phytases. Advanced in Applied Microbiology. 42:263-303.

32. Wyss, M., Brugger, R., Kronenberger, A., Remy, R., Fimbel, R., Oesterhelt, G., Lehmann, M. and Van Loon, A. P. 1999. Biochemical characterization of fungal phytases (myo-inositol hexakisphosphate phosphohydrolases): catalytic properties. Applied and Environmental Microbiology. 65:367-373.

33. Yoon, S. J., Choi, Y. J., Min, H. K., Cho, K. K., Kim, J. W., Lee, S. C. and Jung, Y. H. 1996. Isolation and identification of phytase producing bacterium, Enterobacter sp. 4, and enzymatic properties of phytase enzyme. Enzyme and Microbial Technology. 18:449-454

(접수일자 : 2009. 1. 8. / 수정일자 : 2009. 3. 25. /

채택일자 : 2009. 4. 1.) 